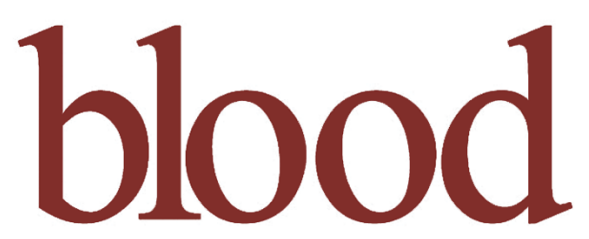

2006 108: 123-133

Prepublished online Mar 9, 2006;

doi:10.1182/blood-2005-11-4458

\title{
Suppression of Fas-FasL coexpression by erythropoietin mediates erythroblast expansion during the erythropoietic stress response in vivo
}

Ying Liu, Ramona Pop, Cameron Sadegh, Carlo Brugnara, Volker H. Haase and Merav Socolovsky

Updated information and services can be found at:

http://bloodjournal.hematologylibrary.org/cgi/content/full/108/1/123

Articles on similar topics may be found in the following Blood collections:

Apoptosis (744 articles)

Hematopoiesis (2346 articles)

Red Cells (1105 articles)

Information about reproducing this article in parts or in its entirety may be found online at:

http://bloodjournal.hematologylibrary.org/misc/rights.dtl\#repub_requests

Information about ordering reprints may be found online at:

http://bloodjournal.hematologylibrary.org/misc/rights.dtl\#reprints

Information about subscriptions and ASH membership may be found online at:

http://bloodjournal.hematologylibrary.org/subscriptions/index.dtl

Blood (print ISSN 0006-4971, online ISSN 1528-0020), is published semimonthly by the American Society of Hematology, 1900 M St, NW, Suite 200, Washington DC 20036.

Copyright 2007 by The American Society of Hematology; all rights reserved.

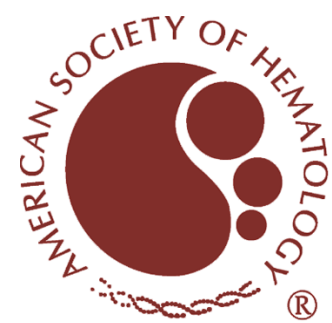




\section{Suppression of Fas-FasL coexpression by erythropoietin mediates erythroblast expansion during the erythropoietic stress response in vivo}

Ying Liu, Ramona Pop, Cameron Sadegh, Carlo Brugnara, Volker H. Haase, and Merav Socolovsky

Erythropoietin (Epo) is the principal regulator of the erythropoietic response to hypoxic stress, through its receptor, EpoR. The EpoR signals mediating the stress response are largely unknown, and the spectrum of progenitors that are stress responsive is not fully defined. Here, we used flow cytometry to identify stress-responsive Ter119 + CD71 ${ }^{\text {high }}$ FSC ${ }^{\text {high }}$ early erythroblast subsets in vivo. In the mouse spleen, an erythropoietic reserve organ, early erythroblasts were present at lower frequencies and were undergoing higher rates of apoptosis than equivalent cells in bone marrow. A high proportion of splenic early erythroblasts coexpressed the death receptor Fas, and its ligand, FasL. Fas-positive early erythroblasts were significantly more likely to coexpress annexin $\mathrm{V}$ than equivalent, Fasnegative cells, suggesting that Fas mediates early erythroblast apoptosis in vivo. We examined several mouse models of erythropoietic stress, including erythrocytosis and $\beta$-thalassemia. We found a dramatic increase in the frequency of splenic early erythroblasts that correlated with down-regulation of Fas and FasL from their cell surface. Further, a single injection of Epo specifically suppressed early erythroblast Fas and FasL mRNA and cell-surface expression. Therefore, Fas and Fas $L$ are negative regulators of erythropoiesis. Epo-mediated suppression of erythroblast Fas and Fas $L$ is a novel stress response pathway that facilitates erythroblast expansion in vivo. (Blood. 2006;108:123-133)

() 2006 by The American Society of Hematology

\section{Introduction}

Multiple clinical and physiologic conditions give rise to tissue hypoxia, resulting in up to a 10-fold increase in red-cell production. ${ }^{1}$ Erythropoietin (Epo), whose receptor is expressed by erythroid progenitors, is the principal regulator of the erythropoietic stress (hereafter referred to simply as 'stress') response. ${ }^{2}$ Epo receptor (EpoR) is a homodimeric type I membrane protein of the cytokine receptor superfamily, ${ }^{3-5}$ closely associated with the cytoplasmic tyrosine kinase Jak2. ${ }^{6-8}$ EpoR and Jak2 are each essential for red-cell formation. ${ }^{9-13}$ Following EpoR ligation, the ensuing Jak2 activation recruits multiple downstream signals including Stat5, PI3 kinase, PLC $\gamma$, PKC, Grb2, Shc, and Ras. ${ }^{6,7}$

The requirement for EpoR signaling may be more stringent during stress than during basal erythropoiesis. Mice expressing reduced numbers of EpoR, ${ }^{14}$ or an EpoR lacking cytoplasmic tyrosines,,${ }^{15}$ have normal basal erythropoiesis, but a deficient stress response. Further, mice lacking Stat5 are also deficient in their stress response and suffer anemia and perinatal death. ${ }^{16-18}$ Therefore, EpoR signals during stress differ quantitatively or qualitatively from the signals required for the formation of red cells per se or for basal erythropoiesis. The intracellular targets of EpoR during stress are largely unknown, and the spectrum of erythroid progenitors in which they act is not fully defined. The recent identification of an activating Jak2 mutation in myeloprolifera- tive disorders ${ }^{19-22}$ emphasizes the importance of identifying physiologic targets of high levels of Jak2 activation, as seen during erythropoietic stress.

The study of erythroid progenitors during stress had been limited by the lack of cell-surface markers with which to identify them in vivo. Previous studies found that the number of erythroid colony-forming units (CFU-Es) in spleen increases dramatically as a result of stress..$^{23-26}$ EpoR is required for CFU-E survival in vitro, ${ }^{27}$ suggesting a similar function during CFU-E expansion in vivo during stress. ${ }^{24,25,27}$ However, to date there are no direct data to support this hypothesis.

The early erythroblast progeny of CFU-Es express the EpoR and are potential Epo targets during stress. ${ }^{28-30}$ Recently, we developed a flow cytometric assay that allows identification of differentiation stage-specific erythroblasts directly in freshly isolated hematopoietic tissue. ${ }^{17}$ We found that early erythroblasts are a target of EpoR-mediated, Stat5-dependent antiapoptotic signaling, through the immediate-early induction of the antiapoptotic protein bcl- $\mathrm{x}_{\mathrm{L}} \cdot{ }^{16}$ The deficient stress response of Stat5-deficient mice was associated with decreased expression of $b c l-x_{\mathrm{L}}$ and decreased survival of their early erythroblasts. These findings therefore suggest the hypothesis that apoptotic regulators in early erythroblasts participate in the stress response.
From the Department of Pediatrics and Department of Cancer Biology, University of Massachusetts Medical School, Worcester; Department of Biology, Massachusetts Institute of Technology, Cambridge; Department of Laboratory Medicine, Children's Hospital, Harvard Medical School, Boston, MA; and Department of Medicine, University of Pennsylvania School of Medicine, Philadelphia.

Submitted November 14, 2005; accepted December 16, 2005. Prepublished online as Blood First Edition Paper, March 9, 2006; DOI 10.1182/blood-2005-11-4458.

Supported by a KO1 Howard Temin award (National Cancer Institute), a Charles H. Hood Foundation Child Health Research Award, an American Cancer Society grant IRG 93-033 (M.S.), and a grant from the Robert Leet and Clara Guthrie Patterson Trust (M.S.).
The online version of this article contains a data supplement.

Reprints: Merav Socolovsky, University of Massachusetts Medical School, Department of Pediatrics, Hematology/Oncology Division, and Department of Cancer Biology, 364 Plantation St, LRB Rm 403, Worcester, MA 01605; e-mail: merav.socolovsky@umassmed.edu.

The publication costs of this article were defrayed in part by page charge payment. Therefore, and solely to indicate this fact, this article is hereby marked "advertisement" in accordance with 18 U.S.C. section 1734

(C) 2006 by The American Society of Hematology 
Here we investigate the role of Fas in erythroblast homeostasis. Fas and its ligand (FasL) are integral membrane proteins of the tumor necrosis factor (TNF) receptor and TNF superfamilies, respectively. ${ }^{31,32}$ Clustering of cell-surface Fas by FasL triggers an intracellular caspase cascade and cell death. ${ }^{32,33}$ Fas and FasL have been detected on cultured erythroblasts, but reports are conflicting regarding the level and differentiation stage at which they are expressed. ${ }^{34-36}$ Fas has been implicated in erythroblast apoptosis in myelodysplastic syndrome, ${ }^{37-40}$ multiple myeloma, ${ }^{41,42} \beta$-thalassemia, ${ }^{43}$ and following stimulation with interferon- $\gamma,{ }^{34}$ underscoring the need to understand its role in erythropoiesis.

Fas and FasL have well-defined functions in immune cells, but have been suggested to also play roles in nonimmune tissue. ${ }^{44-49}$ Mice mutant for Fas (lpr) or FasL (gld) develop a lymphoproliferative autoimmune syndrome. ${ }^{50}$ Of note, lpr mice have increased numbers of multilineage myeloid progenitors (spleen colonyforming units [CFU-Ss]), suggesting that Fas negatively regulates these cells. ${ }^{51}$

Here we investigate Fas function in erythroblast homeostasis in vivo in the mouse, in the basal state and during stress. Our findings suggest that Fas and FasL are Epo-responsive homeostatic regulators of erythropoiesis, a function independent of immune cells or cytokines.

\section{Materials and methods}

Mice

Balb/C (Charles River Laboratories, Wilmington MA), lpr (B6.MRLTnrfsf6 ${ }^{\mathrm{lpr} / \mathrm{j}}$ ), gld (B6Smn.C3-Tnfsf6 ${ }^{\text {gld }} / \mathrm{j}$ ), and C57BL/6J mice (Jackson Laboratories, Bar Harbor, ME) were between 6 and 12 weeks old.

\section{Antibody staining and flow cytometry}

Freshly isolated bone marrow or spleen was strained through a $40-\mu \mathrm{m}$ strainer in the presence of phosphate-buffered saline and 5\% fetal calf serum (PBS/5\% FCS). Cells were immunostained for 20 minutes at $4{ }^{\circ} \mathrm{C}$ in the presence of rabbit IgG (Jackson ImmunoResearch, West Grove, PA), $1 \mu \mathrm{g} / \mathrm{mL}$ fluorochrome-conjugated anti-Ter119 (BD Biosciences, San Diego, CA), and $1 \mu \mathrm{g} / \mathrm{mL}$ fluorochrome-conjugated anti-CD71 (BD Biosciences). 7-AAD (BD Biosciences) or DAPI (Roche, Indianapolis, IN) was used to exclude dead cells. Staining for Fas or FasL was for 1 hour with $5 \mu \mathrm{g} / \mathrm{mL}$ biotin-conjugated anti-Fas (Jo2 clone, ${ }^{52}$ BD Biosciences) or 5 $\mu \mathrm{g} / \mathrm{mL}$ biotin-conjugated anti-FasL (MFL3 clone, ${ }^{53} \mathrm{BD}$ Biosciences) and APC-conjugated streptavidin. To stain for Fas and FasL simultaneously, a FITC-anti-Fas antibody was amplified with a secondary anti-FITC antibody. Annexin V staining was carried out according to the manufacturer's instructions (BD Biosciences). Activated caspase 3 was measured in cells that were first surface labeled for Ter119 and CD71, then fixed, permeabilized, and labeled with a polyclonal rabbit anti-activated caspase 3 (BD Biosciences) or isotype control. In each experimental protocol, the same antibody specificities were used with at least 2 different fluorochrome combinations, yielding similar results. Control samples included unstained cells, single-color controls, and "fluorescence minus one" controls, in each of which one color in turn was missing, to establish the true background for each channel following compensation. Cells were analyzed on a FACSCalibur or LSRII (BD Biosciences) flow cytometers. Data were analyzed with FlowJo software (Tree Star, Stanford University, Stanford, CA). Cell sorting was on a DakoCytomation MoFlo (Fort Collins, CO).

\section{Quantitative real-time PCR}

RNA was prepared from freshly sorted erythroblasts (Ery.A; see "Identification of stress-responsive erythroblast subsets in adult mouse tissue using flow cytometry") using the RNeasy kit (Qiagen, Valencia, CA), treated with DNaseI (Invitrogen, Carlsbad, CA) and concentrated with RNeasy MinElute
Cleanup kit (Qiagen). Reverse-transcription was performed using $1 \mu \mathrm{g}$ RNA/sample, using superscript II (Invitrogen) and random hexamer primers. Real-time polymerase chain reaction (PCR) was conducted on an Applied Biosystems (San Diego, CA) 7300 real-time PCR system. TaqMan probes were used for $18 \mathrm{~S}$ ribosomal RNA (Applied Biosystems catalogue no. 4308329), Fas (catalogue no. Mm00433237), and FasL (catalogue no. Mm00438864). SYBR-green real-time PCR in conjunction with the following primers were used for $\beta$-actin (CACCGAGGCCCCCCT and TTGAAGGTCTCAAACATGATCTGG) and for FasB (GAGGCCCATTTTGCTGTCAA and CCTACGTGGCCAGGAATCAG). A single PCR product for each of these PCRs was confirmed by gel electrophoresis and by melting-curve analysis. In all cases, no product was obtained in the absence of template or the absence of reverse transcriptase.

\section{Results}

\section{Identification of stress-responsive erythroblast subsets in adult mouse tissue using flow cytometry}

We previously developed a flow cytometric assay to identify stage-specific erythroblasts directly in hematopoietic tissue. ${ }^{17} \mathrm{We}$ and others have applied this assay in the study of erythroblasts in vivo. ${ }^{17,54-59}$ Intermediate levels of Ter119 (Ter119 ${ }^{\text {med }}$ CD71 ${ }^{\text {high }}$ ) identify proerythroblasts (ProEs). ${ }^{17}$ Ter $119^{\text {high }}$ cells are subdivided, based on their expression of the transferrin receptor (CD71), which declines with erythroblast maturation. However, the decline in CD71 appeared gradual, without the formation of well-resolved subpopulations. This resulted in the need to subdivide Ter119high erythroblasts arbitrarily into high, medium, and low expressors of CD71, corresponding to increasingly mature erythroblasts. ${ }^{17}$

In the present work we distinguished well-resolved erythroblast subpopulations by considering, in addition to Ter119 and CD71, the forward scatter (FSC) parameter. FSC is a function of cell size and had been used previously to assess erythroblast maturation, independently of cell-surface marker expression. ${ }^{17,60}$ Figure 1A shows that when Ter119 ${ }^{\text {high }}$ cells are analyzed using both the CD71 and FSC parameters, they consistently resolve into 3 principal populations, which we labeled A, B, and C erythroblasts (Ery.A, Ery.B, and Ery.C). Cytospin analysis of these subpopulations shows that they form a developmental sequence. Ery.A (Ter119 ${ }^{\text {high }}$ CD $71^{\text {high }} \mathrm{FSC}^{\text {high }}$ ) are basophilic, Ery.B (Ter119 $\left.{ }^{\text {high }} \mathrm{CD} 71^{\text {high }} \mathrm{FSC}^{\text {low }}\right)$ are late basophilic and polychromatic, whereas Ery.C (Ter119 ${ }^{\text {high }}$ CD $71^{\text {low }}$ FSC ${ }^{\text {low }}$ ) are orthochromatic erythroblasts and reticulocytes (Figure 1B).

We found that the ProE, Ery.A, Ery.B, and Ery.C subsets differ in their sensitivity to stress. We mimicked the effect of acute stress by injecting mice with a single dose of Epo $(50 \mathrm{mg} / \mathrm{kg})$. Figure 2 shows ensuing changes in hematopoietic tissue in vivo. Spleen size increased approximately 2.5 -fold by 72 hours after injection (Figure 2A) and there was an associated increase in hematocrit (Figure 2B). The frequency of Ter $119^{+}$cells within the spleen increased to 1.6-fold the basal level by 72 hours (Figure 2C). Therefore, the absolute number of all splenic Ter119 ${ }^{+}$cells increased $2.5 \times 1.6=4$-fold at this time. The frequency of Ter119 ${ }^{+}$ cells also increased in bone marrow (Figure 2C).

We found that the relative proportions of the various erythroblast subsets altered following Epo injection. By 72 hours, the proportion of splenic ProEs and Ery.A within Ter119+ cells increased 10-fold and 6-fold, respectively, their absolute number increasing 40-fold and 24-fold (Figure 2D-F). In bone marrow, where the basal levels of ProEs and Ery.A are higher than in spleen, their proportion also increased, peaking by 24 hours (Figure 2D-F). There was an approximately 2-fold, delayed increase in the 
A
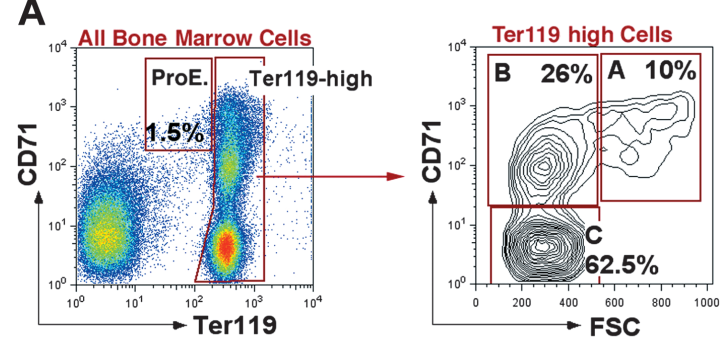

B

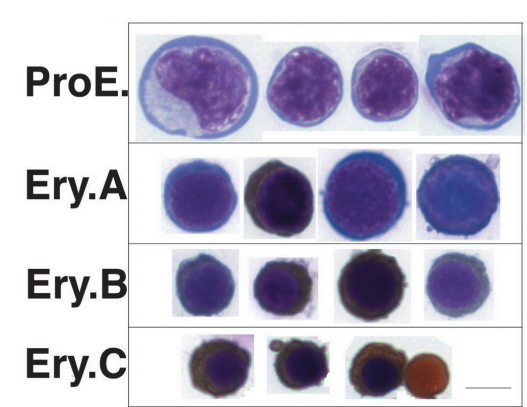

Figure 1. Definition of flow cytometric erythroblast subsets. (A) Flow cytometric analysis of freshly isolated bone marrow cells labeled with antibodies against Ter119 and CD71. Dead cells were excluded with 7-AAD. The left panel shows all viable bone marrow cells. Ter119high cells are further analyzed with respect to their forward scatter (FSC) in the right panel. (B) Cytospin preparations of cells sorted from the ProEs and Ery.A, B, and $C$ subsets shown in panel $A$ are stained for hemoglobin with diaminobenzidine and counterstained with Giemsa. Scale bar represents $5 \mu \mathrm{m}$.

proportion of splenic and bone marrow Ery.B, their absolute number increasing approximately 8 -fold by 96 hours. The proportion of the most mature, Ery.C subset, declined 4-fold in spleen, suggesting their absolute number remained unchanged.
The rapid increase in ProEs and Ery.A suggests they are a direct Epo target during stress. The delayed response of Ery.B suggests they are less responsive to Epo. Their increase may be secondary to that in Ery.A, from which they arise. The lack of a significant increase in Ery.C by 96 hours may reflect the time required for their maturation from earlier precursors and may be contributed to by the accelerated release of late erythroblasts from hematopoietic tissue in response to high Epo.

\section{The frequency and survival of ProEs and Ery.A in spleen is lower than in bone marrow}

In the basal state, Ery.A and ProEs were present at lower frequencies in spleen than in bone marrow (Figures $2 \mathrm{~F}$ and $3 \mathrm{~A}$ ), in inbred mouse strains Balb/C and C57BL6, and in mixed genetic background mice $(\mathrm{C} 57 \mathrm{BL} 6 \times 129)$. In Balb/C $(\mathrm{n}=7)$, the mean frequency of ProEs within Ter $119^{+}$cells was $2.5 \% \pm 0.5 \%$ (mean \pm SEM) in bone marrow but only $0.5 \% \pm 0.1 \%$ in spleen $(P<.01$, 2-tailed Student $t$ test). The frequency of Ery.A in spleen was $11 \% \pm 3.2 \%$ compared with $26 \% \pm 3.4 \%$ in bone marrow $(P<.01)$.

We examined the survival of early erythroblasts in bone marrow and spleen using annexin $\mathrm{V}$ binding ${ }^{61}$ and caspase 3 activation. ${ }^{62}$ Freshly isolated spleen and bone marrow cells were labeled for expression of CD71 and Ter119, annexin V binding, and the viability dye 7 -amino-actinomycin $\mathrm{D}(7-\mathrm{AAD}),{ }^{63}$ and examined by flow cytometry. Figure 3B shows a representative analysis of annexin $\mathrm{V}$ binding in Ery.A. Figure 3C summarizes results from several similar experiments for each of the erythroblast subsets. Annexin $\mathrm{V}$ binding was 3-fold higher in Ery.A in spleen than in bone marrow $(P<.001)$. Significantly higher annexin $\mathrm{V}$ binding was also seen in splenic ProEs and Ery.B compared with the equivalent bone marrow subsets.
A

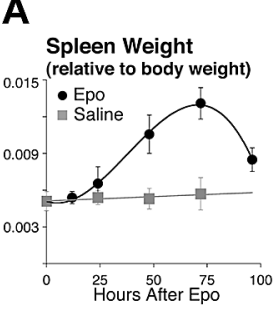

B

Hematocrit (\%)

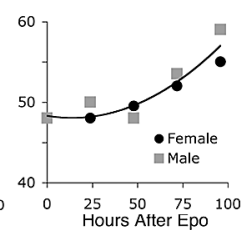

C i

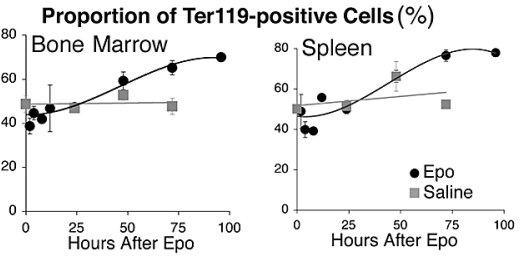

D

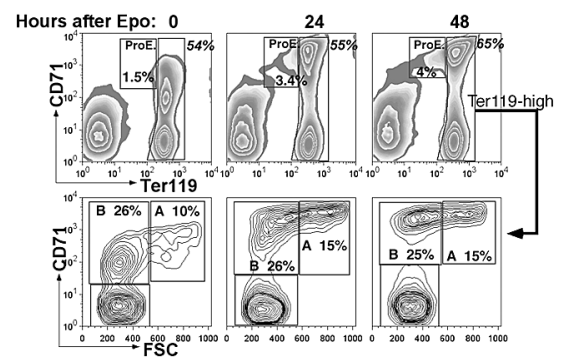

E

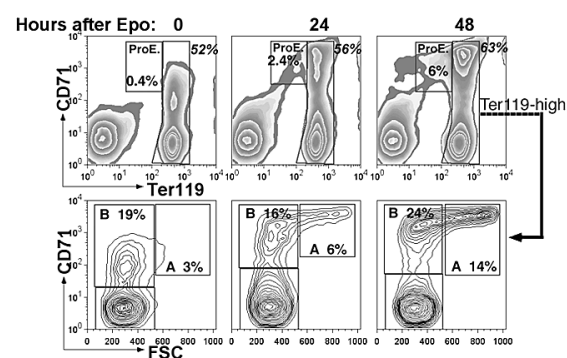

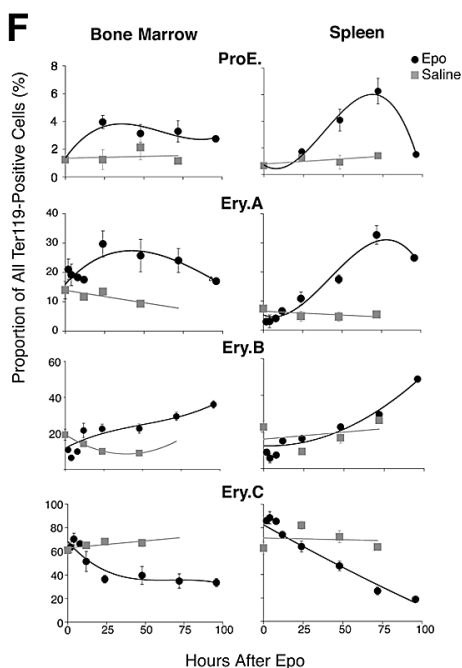

Hours After Epo

Figure 2. Epo-responsive erythroblast subsets in bone marrow and spleen. Wild-type mice were injected with a single dose of Epo (50 mg/kg) or an equal volume of saline, and followed for up to 96 hours. Bone marrow and spleen cells were freshly isolated and analyzed. The results of 7 independent experiments were pooled. Each data point is the mean $\pm \mathrm{SEM}$ of 2 to 9 mice. Each experiment contained mice of a single sex or an equal number of females and males. There was no significant difference between the Epo response of male and female mice. (A-C) Epo caused a transient increase in spleen weight (A), hematocrit (B), and in the proportion of Ter119 ${ }^{+}$cells in both bone marrow (Ci) and spleen (Cii). (D-E) Examples of flow cytometric histograms of bone marrow (D) and spleen (E) cells labeled with Ter119 and CD71 antibodies and analyzed as illustrated in Figure 1. There is a clear increase in the proportions of the ProE and Ery.A subsets in both tissues, with a moderate increase in Ery.B. (F) Changes in the relative frequencies of erythroblast subsets within the Ter119 ${ }^{+}$compartment in bone marrow or spleen, following Epo injection or a control saline injection. Data were analyzed as illustrated in panels $\mathrm{D}-\mathrm{E}$, and mean values for data pooled from 7 experiments are presented. 
A

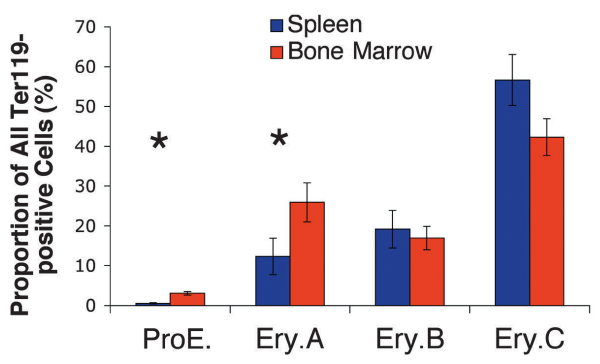

B
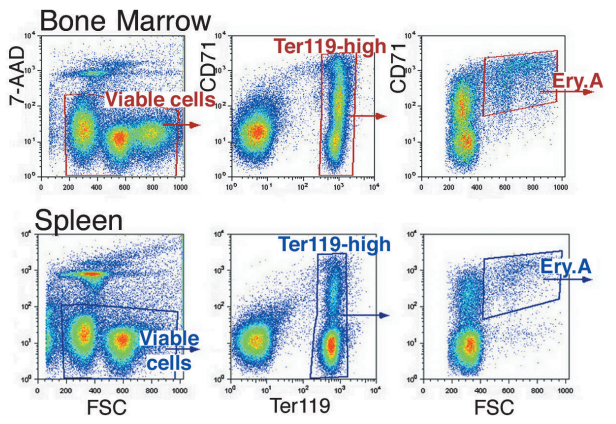

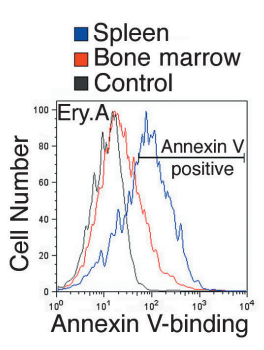

C

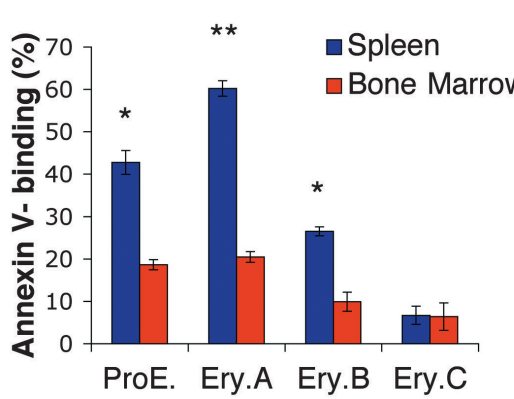

D

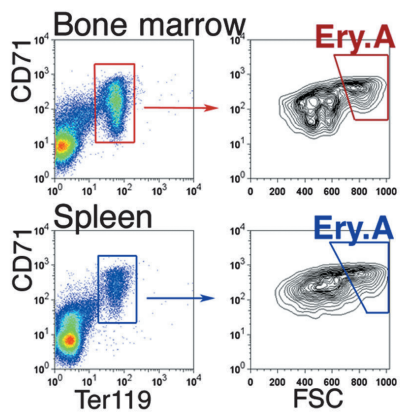

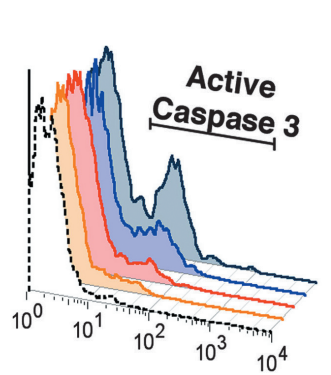

- Control

Bone marrow $13 \%$ Bone marrow $2 \%$ Spleen $1 \quad 20 \%$ Spleen $2 \quad 13 \%$

Figure 3. Lower frequency and higher apoptosis of splenic early erythroblast subsets in the basal state. (A) The ProE and Ery.A subsets are a lower proportion of Ter119+ cells in spleen than in bone marrow. Data are the mean \pm SEM from Balb/C mice $(\mathrm{n}=7)$. ${ }^{*}$ Student $t$ test $(2$-tailed, unequal variance), $P<.01$. (B) Higher annexin $\mathrm{V}$ binding of splenic Ery.A compared with equivalent bone marrow cells. Viable cells (impermeable to 7-AAD) from either bone marrow (top panels) or spleen (bottom panels) were analyzed for Ter119/CD71 expression. Ter119high cells were gated and further analyzed with respect to FSC. FSChigh CD71 high cells (Ery.A) were examined for annexin V binding (right panel). Background fluorescence in the annexin $\mathrm{V}$ channel was determined by comparison with Ery.A cells stained for all colors except for annexin $\mathrm{V}$ ("fluorescence minus one" or FMO-annexin V, gray curve). The following fluorescent conjugates were used: CD71-FITC, Ter119-APC, 7-AAD, annexin V-Alexa Fluor 350. Controls included unstained cells, single-color controls, and FMO controls. (C) Higher annexin $\mathrm{V}$ binding in splenic erythroblasts compared with equivalent bone marrow erythroblasts. Staining strategy and data analysis as in panel B, for each of the indicated erythroblast subsets. Mean $\pm \mathrm{SEM}, \mathrm{Balb} / \mathrm{C}$ mice $(\mathrm{n}=4)$; ${ }^{*} P<.003 ;{ }^{\star \star} P<.001$. (D) Higher proportion of cells positive for activated caspase 3 in splenic than in bone marrow Ery.A. The proportion (\%) of cells staining positive for caspase 3 in each tissue is indicated. Representative experiment; tissue from 2 Balb/C mice.

To assess caspase 3 activation, splenic and bone marrow cells were labeled for cell-surface Ter119 and CD71, and intracellularly for the activated form of caspase 3. In spleen, a higher proportion of Ery.A was positive for activated caspase 3, compared with bone marrow Ery.A (Figure 3D). Thus, by 2 independent measures of apoptosis, splenic Ery.A undergo significantly more apoptosis than equivalent bone marrow cells.

\section{Fas and FasL are coexpressed by splenic early erythroblasts}

The higher apoptosis of splenic early erythroblasts (Figure 3B-D) may account for their lower relative frequencies (Figure 3A). We therefore examined potential apoptotic regulators of early erythroblasts. Fas and FasL have been detected on cultured erythroblasts. ${ }^{34-36}$ To examine their expression in vivo, we labeled freshly explanted splenic and bone marrow cells for cell-surface Ter119, CD71, and either Fas or FasL. We found that erythroblasts expressed both Fas and FasL (Figure 4A-B). The highest expression frequencies for both Fas and FasL were in the least mature, ProE and Ery.A subsets, and declined with erythroblast maturation. Only a proportion of ProE and Ery.A subsets, however, expressed Fas or FasL. Of note, Fas and FasL were expressed by a significantly higher proportion of splenic, compared with bone marrow, erythroblasts. There was no significant difference between bone marrow and spleen, however, in Fas and FasL expression by nonerythroid cells (Figure 4A-B). Similar Fas and FasL expression patterns were found in C57BL6/129 mice (Figure 4A-B) and in Balb/C mice (not shown), with $30 \%$ to $50 \%$ of splenic Ery.A expressing Fas and $60 \%$ to $80 \%$ expressing FasL.
Our finding that Fas and FasL are coexpressed in vivo within the same erythroblast subsets differs from that reported for cultured human erythroblasts, ${ }^{35,64}$ where Fas and FasL appeared to be expressed sequentially in differentiation. To investigate this further, we sorted freshly isolated ProEs or Ery.A expressing either Fas or FasL and compared their morphology in cytospin preparations (not shown). We found that, within a given erythroblast subset, cells expressing Fas had a similar morphology to cells expressing FasL, confirming that even within a given subset, cells expressing Fas or FasL are of a similar maturation.

We examined whether Fas and FasL are coexpressed within the same cell by labeling spleen and bone marrow cells simultaneously with antibodies directed against Fas and FasL, as well as Ter119 and CD71. We found that, within splenic Ery.A, more than $90 \%$ of cells expressing Fas also coexpress FasL (Figure 4C).

\section{Fas-positive erythroblasts in vivo are more likely to bind annexin V}

The tissue and differentiation stage pattern of erythroblast Fas and FasL expression (Figure 4A-B) was similar to that of annexin V binding (Figure 3C). We therefore examined whether Fas may be responsible for splenic erythroblast apoptosis. We asked whether, within the same erythroblast subset, Fas-positive cells are more likely to express annexin $\mathrm{V}$ than Fas-negative cells. We labeled freshly isolated spleen and bone marrow cells simultaneously with annexin V and with antibodies against Fas, Ter119, and CD71. Fas-positive ProEs (not shown) and Ery.A (Figure 4D) bound annexin $\mathrm{V}$ with higher frequencies than Fas-negative cells of the 

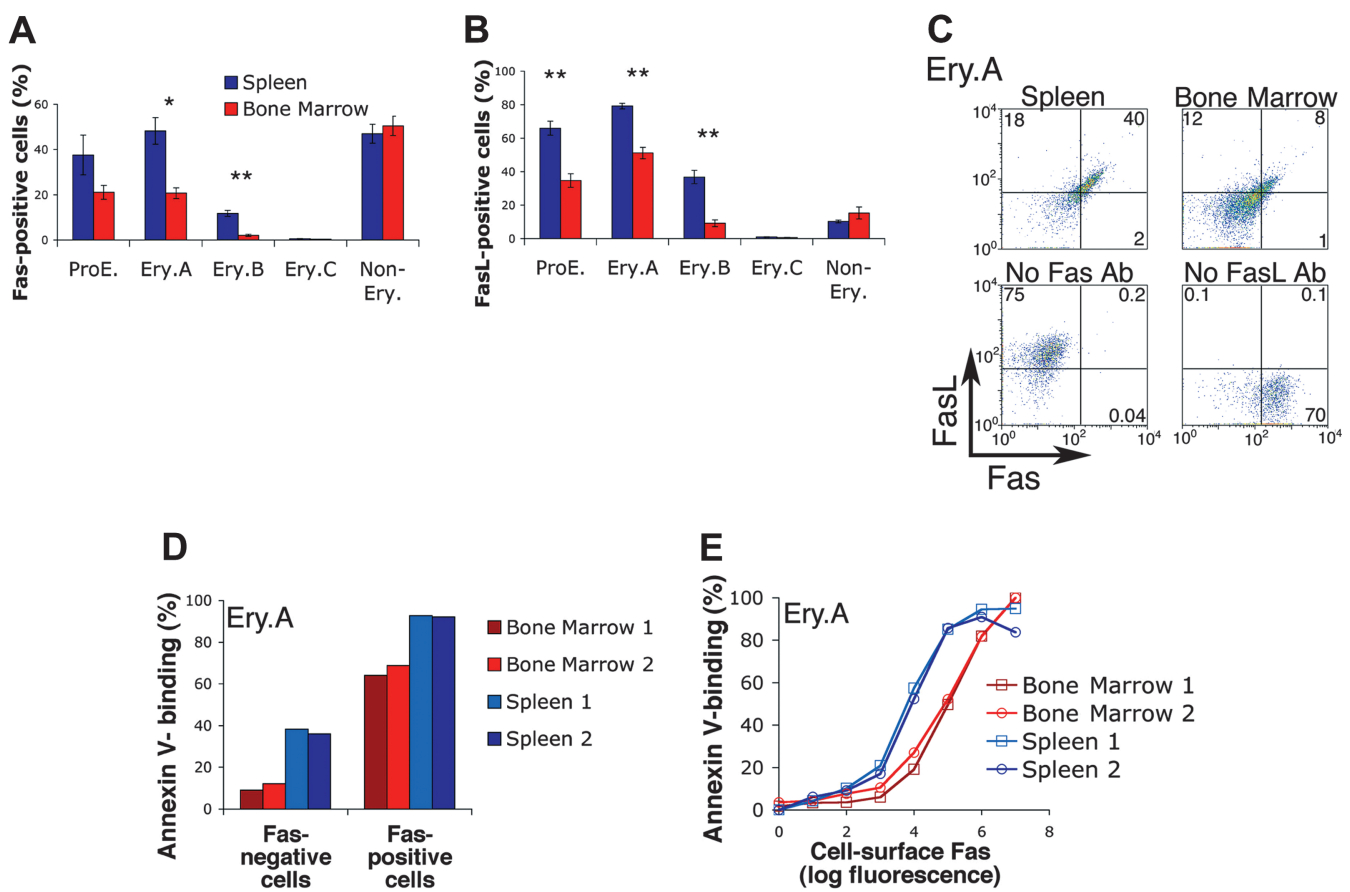

Figure 4. Fas and FasL are coexpressed by early erythroblasts and mediate early erythroblast apoptosis in vivo. (A-B) Expression of Fas (A) or FasL (B) in spleen and bone marrow cells. Both Fas and FasL are expressed at higher frequencies in ProE and Ery.A subsets. Both are also expressed at higher frequencies in spleen than in bone marrow. Freshly isolated spleen and bone marrow were labeled with antibodies against Ter119, CD71, and either Fas (Jo2) or FasL (MFL3). Staining strategy and analysis were similar to those described in Figure 3. Data from C57BL6/129 mice, $\mathrm{n}=5$, mean \pm SEM. ${ }^{*} P<.004 ;{ }^{* \star} P<.001$. (C) Fas and FasL are coexpressed by Ery.A in spleen (top left panel) and bone marrow (top right panel). Ter119/CD71/FSC analysis was used to gate Ery.A, as illustrated in Figure 1. Bottom panels show FMO controls (Figure 3B), which were used to set background fluorescence in Ery.A. These lack either Fas or FasL primary antibodies, as indicated, but contain secondary and all other primary antibodies. Representative of 3 experiments. Two different combinations of fluorescent conjugates gave similar results. (D-E) Single-cell analysis of Fas expression and annexin V binding in spleen and bone marrow Ery.A. Freshly isolated bone marrow and spleen cells were simultaneously labeled with annexin $\mathrm{V}$ and with antibodies to Ter119, CD71, and Fas. Fas-positive Ery.A are several-fold more likely to bind annexin $\mathrm{V}$ than Fas-negative cells (D). In panel E, Ery.A were subdivided into 8 subsets of increasing Fas expression, measured as geometric mean fluorescence per cells. Fas expression is correlated with annexin $\mathrm{V}$ binding, in both spleen and bone marrow. Data are from Balb/C mice $(n=2)$.

same subset. Thus, $90 \%$ of Fas-positive splenic Ery.A bound annexin V compared with only $40 \%$ of Fas-negative splenic Ery.A. Similarly, more than $60 \%$ of bone marrow Fas-positive Ery.A bound annexin $\mathrm{V}$, compared with only $10 \%$ of equivalent Fasnegative cells (Figure 4D). Further, the level of Fas expression directly correlated with annexin V-binding, and virtually all cells expressing the highest levels of Fas were positive for annexin $\mathrm{V}$ (Figure 4E). For a given Fas expression level, bone marrow Ery.A were consistently less likely to be annexin $\mathrm{V}$ positive than splenic Ery.A (the red curves are right-shifted relative to the blue curves; Figure 4E). Because Fas-mediated apoptosis requires the Fas-FasL interaction, this difference may be due to the lower frequency of FasL expression in bone marrow Ery.A (Figure 4B). The presence of splenic Ery.A that are Fas negative but annexin $\mathrm{V}$ positive suggests that, in addition to Fas, other apoptotic regulators are active in these cells.

The strong correlation, at the single-cell level, between Fas expression and annexin $\mathrm{V}$ binding suggests that Fas expressed by early erythroblasts in vivo is functional and is mediating cell death in the basal state.

\section{Fas expressed by freshly isolated Ery.A and Ery.B is functional}

Erythroblasts differentiating in vitro express functional Fas. ${ }^{34-36}$ To confirm that Fas expressed by freshly isolated erythroblasts is also functional, we incubated freshly sorted splenic Ery.A or Ery.B for up to 6 hours in the presence of Epo $(0.05 \mathrm{U} / \mathrm{mL})$ and either in the presence or absence of the agonistic anti-mouse Fas antibody Jo2. ${ }^{52}$ Apoptosis was assessed using annexin V-binding and found to be higher in Ery.A than in Ery.B (Figure S1, available on the Blood website; see the Supplemental Figures link at the top of the online article). The presence of the agonistic anti-Fas antibody significantly increased annexin $\mathrm{V}$ binding in both subsets, suggesting splenic erythroblasts express functional Fas.

\section{Analysis of Ipr and gld mice}

We examined mice mutant for Fas (lpr) or its ligand (gld). ${ }^{50}$ Splenic ProE. and Ery.A in $1 \mathrm{pr}$ and gld mice were present at higher frequencies than in matched, wild-type mice (Figure S2). These findings are consistent with Fas-mediated apoptosis of ProE. and Ery.A in wild-type mice in the basal state (Figure 4). However, a proportion of lpr and gld mice suffered mild to moderate anemia, a consequence of their autoimmune syndrome. ${ }^{50}$ Therefore, increased ProE. and Ery.A frequency may reflect, in part, a stress response to anemia. We are currently developing mouse models that would enable us to distinguish these possibilities.

\section{Fas and FasL expression in mouse models of chronic erythropoietic stress}

Fas-mediated apoptosis of splenic early erythroblasts would limit basal erythropoietic rate. We therefore asked whether, during stress, erythroblasts become resistant to Fas-mediated apoptosis.

Mice heterozygous for $b 1$ and $b 2$ adult globin gene deletions suffer $\beta$-thalassemia ( $\beta$-thal), manifesting low hematocrits $(34 \% \pm 1.7 \%$, mean $\pm \mathrm{SD}, \mathrm{n}=7$, compared with $45 \% \pm 2.5 \%$ in wild-type littermates, $\mathrm{n}=12$ ), compensatory splenomegaly, and erythroid hyperplasia. ${ }^{65}$ We examined freshly isolated spleen and bone marrow from adult $\beta$-thal mice and from wild-type littermates. We found a clear increase in the number of Ter $119^{+}$cells in 
A
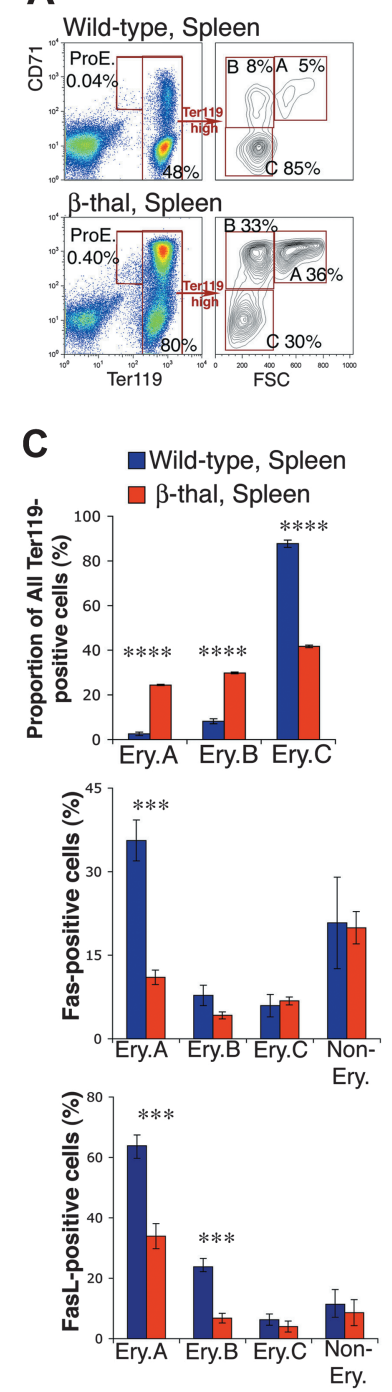

Figure 5. Down-regulation of cell-surface Fas and FasL in early erythroblasts from $\boldsymbol{\beta}$-thal mice. (A) Representative flow cytometric histograms showing an example of the changes found in erythroblast frequencies within Ter119+ cells in spleen in a $\beta$-thal mouse compared with a littermate wild-type mouse. (B) Representative flow cytometric histograms of Fas and FasL expression in spleen Ery.A, B, and $C$, in $\beta$-thal erythroblasts, and in erythroblasts from a wild-type littermate. The percentage of Ery.A positive for Fas relative to FMO control (not shown) is shown in red. The percentage of Ery.B positive for Fas is shown in blue. (C-D) Changes in erythroblast subset frequencies, and in Fas and FasL expression, in spleen $(C)$ and bone marrow (D), in $\beta$-thal mice $(n=8)$ compared with littermate wild-type mice $(n=8)$. Data are mean \pm SEM. Spleen and bone marrow cells were analyzed as illustrated in panels A-B. ${ }^{*} P<.05,{ }^{* \star} P<.01,{ }^{* \star \star} P<.001,{ }^{\star \star \star *} P<.001$.

spleen, from $43 \% \pm 1.7 \%$ (mean $\pm \mathrm{SEM}, \mathrm{n}=8$ ) to $68 \% \pm 2.7 \%$ (n $=8, P<.001$ ), reflecting erythroid hyperplasia. The frequencies of Ery.A and Ery.B increased disproportionately, 10-fold and 5-fold, respectively (Figure 5A,C upper panels). There were also significant increases in the frequencies of bone marrow early erythroblasts (Figure 5D upper panel).

Early erythroblast expansion was associated with a significant reduction in cell-surface Fas/FasL in $\beta$-thal mice compared with wild-type littermates (Figure 5B-D). There was a 3-fold reduction in Fas-positive splenic Ery.A. The frequency of FasL-positive cells in $\beta$-thal mice fell 2-fold and 3-fold in splenic Ery.A and Ery.B, respectively $(P<.001)$. Cell-surface Fas and FasL in wild-type bone marrow Ery.A is already low, but it declined further in $\beta$-thal mice (Figure 5D). Unlike erythroblast Fas/FasL, there was no down-regulation of Fas or FasL in nonerythroid cells in $\beta$-thal spleen or bone marrow (Figure 5C-D).

We also examined mice with a kidney- and liver-specific deletion of the von Hippel-Lindau (VHL) gene (ts-VHL ${ }^{-1-}$ mice). ${ }^{66,67}$ The constitutively elevated Epo in these mice ${ }^{68}$ leads to chronic erythrocytosis, ${ }^{66}$ with hematocrits ranging from $65 \%$ to $80 \%$ compared with $45 \%$ to $55 \%$ in wild-type littermates. ${ }^{66}$ They manifest moderately enlarged spleens with increased numbers of Ter $119^{+}$cells. The frequency of splenic Ery.A and Ery.B is increased (Table 1). This is associated with a 4-fold and 2-fold decrease in the frequency of Fas-positive splenic ProEs and Ery.A, respectively. FasL expression was also significantly lower (Table 1). There were no significant changes in erythroblast frequencies or Fas/FasL expression in ts- $\mathrm{VHL}^{-1-}$ bone marrow.

Pregnancy is a subacute form of erythropoietic stress. ${ }^{69} \mathrm{We}$ examined freshly isolated bone marrow and spleen from pregnant $\mathrm{Balb} / \mathrm{C}$ mice and compared them with strain and age-matched nonpregnant females. We found a $10 \%$ increase in the frequency of Ery.A in both spleen and bone marrow, relative to all Ter119 ${ }^{+}$cells $(P<.05, \mathrm{n}=5)$. This was associated with a statistically significant decrease in cell-surface Fas and FasL expression in Ery.A in both spleen and bone marrow (Table 2).

Taken together, early erythroblast cell-surface Fas and FasL are down-regulated in erythropoietic stress conditions of different etiologies: $\beta$-thalassemia, ts- $\mathrm{VHL}^{-1-}$ mice, and pregnant mice. This suggests that down-regulation of Fas and FasL expression may be intrinsic to the erythropoietic stress response itself.

\section{Acute Epo administration leads to down-regulation of erythroblast Fas and FasL}

Erythropoietic stress is regulated by several hormones and cytokines. ${ }^{70-73}$ To examine the role of Epo in Fas/FasL down-regulation during stress, we injected wild-type Balb/C mice with a single Epo dose (50 $\mathrm{mg} / \mathrm{kg}$ subcutaneously), or with an equal volume of saline (Figures 2 and 6), and examined changes in erythroblast frequencies (Figure 2), apoptotic markers and Fas/FasL expression (Figure 6 ) over the ensuing 96 hours. Epo caused a fall in cell-surface Fas and FasL, which reached their lowest levels in splenic Ery.A by 48 hours, beginning to recover toward baseline levels by 96 hours (Figure 6A-B). In parallel, there was a fall in annexin $\mathrm{V}$ binding in ProEs and Ery.A (Figure 6A,C), and a decline in activated caspase 3 (Figure 6D). These data suggest that high Epo, alone, is sufficient to cause down-regulation of cell-surface Fas and FasL in splenic early erythroblasts.

\section{Quantitative real-time PCR of Fas, FasB, and FasL mRNA}

To examine the mechanisms of Fas/FasL down-regulation during stress, we measured early erythroblast Fas and FasL mRNA as well as mRNA for the alternatively spliced, soluble FasB isoform, using quantitative real-time PCR. RNA was prepared from freshly sorted splenic Ery.A, from mouse models of stress, or from matched control mice (Figure 6E; Table 3). Total Fas mRNA decreased significantly by 24 hours following Epo injection and was 5-fold lower than the basal level by 72 hours (Figure 6E). mRNA levels for FasL also decreased. FasB mRNA decreased in parallel with total Fas mRNA (Figure 6E). These results are consistent with Epo-mediated suppression of Fas and FasL transcription. Alternatively, Epo may mediate increased degradation of Fas or FasL mRNA.

We also examined Fas, FasB, and FasL mRNAs in splenic Ery.A from $\beta$-thal and ts- $\mathrm{VHL}^{-1-}$ mice and compared them with matched controls (Table 3 ). In both these mouse models, there was 
From www.bloodjournal.org at UNIV OF MASSACHUSETTS on April 3, 2008. For personal use only.

Table 1. Down-regulation of splenic erythroblast cell-surface Fas/FasL in ts-VHL ${ }^{-1-}$ mice

\begin{tabular}{|c|c|c|c|c|c|c|c|c|c|}
\hline & \multicolumn{3}{|c|}{ Subset frequency, $\%$ of Ter $119^{+}$cells } & \multicolumn{3}{|c|}{ Fas-positive cells, $\%$} & \multicolumn{3}{|c|}{ FasL-positive cells, \% } \\
\hline & $\begin{array}{c}\text { Control }^{*} \\
n=6\end{array}$ & $\begin{array}{c}\text { ts-VHL }{ }^{-l-} \\
\mathrm{n}=5\end{array}$ & $P \dagger$ & $\begin{array}{c}\text { Control }^{*} \\
n=6\end{array}$ & $\begin{array}{c}\text { ts-VHL }^{-l-} \\
\mathrm{n}=\mathbf{5}\end{array}$ & $P \dagger$ & $\begin{array}{c}\text { Control }^{*} \\
n=6\end{array}$ & $\begin{array}{c}\text { ts-VHL }{ }^{-l-} \\
\mathrm{n}=5\end{array}$ & $P \dagger$ \\
\hline \multicolumn{10}{|l|}{ Spleen } \\
\hline ProE & $0.6 \pm 0.2$ & $1.5 \pm 0.3$ & - & $38 \pm 9$ & $9 \pm 3$ & .023 & $66 \pm 4$ & $36 \pm 9$ & .025 \\
\hline Ery.A & $24 \pm 5$ & $36 \pm 3$ & .044 & $48 \pm 6$ & $26 \pm 3$ & .011 & $79 \pm 2$ & $60 \pm 5$ & .018 \\
\hline Ery.B & $24 \pm 4$ & $39 \pm 3$ & .012 & $12 \pm 1$ & $3 \pm 0.4$ & $<.001$ & $37 \pm 4$ & $12 \pm 4$ & .002 \\
\hline Ery.C & $52 \pm 8$ & $24 \pm 4$ & .045 & $0.6 \pm 0.1$ & $0.3 \pm 0.1$ & - & $1 \pm 0.2$ & $0.6 \pm 0.2$ & - \\
\hline Non-Ery & NA & NA & - & $47 \pm 4$ & $47 \pm 6$ & - & $10 \pm 0.2$ & $9 \pm 1$ & - \\
\hline \multicolumn{10}{|c|}{ Bone marrow } \\
\hline ProE & $1.9 \pm 0.3$ & $2.0 \pm 0.4$ & - & $21 \pm 3$ & $13 \pm 3$ & - & $35 \pm 4$ & $28 \pm 5$ & - \\
\hline Ery.A & $35 \pm 4$ & $35 \pm 5$ & - & $21 \pm 2$ & $17 \pm 4$ & - & $51 \pm 3$ & $41 \pm 4$ & - \\
\hline Ery.B & $34 \pm 2$ & $25 \pm 1$ & .001 & $2 \pm 0.5$ & $1 \pm 0.2$ & - & $9 \pm 2$ & $6 \pm 2$ & - \\
\hline Ery.C & $29 \pm 4$ & $38 \pm 6$ & - & $0.3 \pm 0.05$ & $0.3 \pm 0.1$ & - & $0.6 \pm 0.1$ & $0.3 \pm 0.1$ & - \\
\hline Non-Ery & NA & NA & - & $51 \pm 4$ & $50 \pm 3$ & - & $15 \pm 4$ & $18 \pm 5$ & - \\
\hline
\end{tabular}

Non-Ery indicates nonerythroid; NA, not applicable; and -, not significant.

*Matched littermates, number of mice indicated (n).

$\dagger$ Two-tailed Student $t$ test, unequal variance, only for statistically significant differences at $P<.05$.

a significant decrease in Fas and FasB mRNA. Fas mRNA was 6 -fold lower in $\beta$-thal mice than in wild-type littermates and 3-fold lower in ts- $\mathrm{VHL}^{-/-}$mice. These mRNA levels correlate well with the more pronounced fall in splenic Ery.A surface Fas expression in $\beta$-thal than in ts-VHL ${ }^{-1-}$ mice (Figure 5; Table 1). FasL mRNA was significantly reduced in ts- $\mathrm{VHL}^{-1-}$ mice, suggesting, in agreement with our results in mice injected with Epo, that Epo suppresses FasL mRNA expression. However, in $\beta$-thal mice, where the stress response is likely to be mediated by Epo in cooperation with other stress factors, the levels of FasL mRNA were more variable (Table 3 ).

\section{The frequency of splenic Ery.A is a function of their Fas expression}

We asked how Fas expression in Ery.A correlates with Ery.A expansion (Figure 7A), across all the erythropoietic models we examined. We plotted the mean increase in Ery.A frequency for each of the stress conditions against the corresponding mean decrease in Fas-positive Ery.A. The increase in Ery.A frequency was inversely related to the square of the fraction of Ery.A expressing Fas. It is therefore likely that the decrease in Fas is itself

Table 2. Down-regulation of erythroblast Fas/FasL in pregnant mice

\begin{tabular}{lcclllll}
\hline & \multicolumn{3}{c}{ Fas-positive cells, $\%$} & & \multicolumn{3}{c}{ FasL-positive cells, \% } \\
\cline { 2 - 3 } & $\begin{array}{c}\text { Control*; } \\
\mathbf{n}=\mathbf{5}\end{array}$ & $\begin{array}{c}\text { Pregnancy; } \\
\mathbf{n}=\mathbf{5}\end{array}$ & $\boldsymbol{P \dagger}$ & $\begin{array}{c}\text { Control*; } \\
\mathbf{n}=\mathbf{5}\end{array}$ & $\begin{array}{c}\text { Pregnancy; } \\
\mathbf{n}=\mathbf{5}\end{array}$ & $\boldsymbol{P} \boldsymbol{\dagger}$ \\
\hline Spleen & & & & & & \\
ProE & $35 \pm 8$ & $16 \pm 5$ & - & $55 \pm 6$ & $40 \pm 4$ & - \\
Ery.A & $36 \pm 3$ & $25 \pm 3$ & .022 & $73 \pm 5$ & $59 \pm 3$ & .042 \\
Ery.B & $4 \pm 1$ & $1.5 \pm 0.2$ & - & $17 \pm 5$ & $9 \pm 2$ & - \\
Ery.C & $0.6 \pm 0.2$ & $0.4 \pm 0.1$ & - & $2 \pm 1.5$ & $0.8 \pm 0.4$ & - \\
Non-Ery & $30 \pm 4$ & $33 \pm 5$ & - & $5 \pm 0.6$ & $5 \pm 1$ & - \\
Bone & & & & & & \\
marrow & & & & & & \\
ProE & $18 \pm 4$ & $12 \pm 4$ & - & $43 \pm 10$ & $16 \pm 4$ & - \\
Ery.A & $13 \pm 1$ & $9 \pm 1$ & .044 & $59 \pm 8$ & $28 \pm 3$ & .013 \\
Ery.B & $0.7 \pm 0.1$ & $0.7 \pm 0.1$ & - & $7 \pm 2$ & $4 \pm 2$ & - \\
Ery.C & $0.3 \pm 0.1$ & $0.4 \pm 0.1$ & - & $1 \pm 0.5$ & $0.6 \pm 0.4$ & - \\
Non-Ery & $20 \pm 2$ & $24 \pm 5$ & - & $9 \pm 2$ & $12 \pm 1$ & - \\
\hline
\end{tabular}

— indicates not significant.

*Age- and strain-matched (Balb/C) mice.

†Two-tailed Student $t$ test, unequal variance, only for statistically significant differences at $P<.05$. a function of the degree of erythropoietic stress. The fraction of Ery.A that is Fas positive is, in turn, an important regulator of Ery.A frequency.

\section{Discussion}

We defined stress-responsive erythroblast subsets in mouse hematopoietic tissue using flow cytometry. ProEs (Ter119 ${ }^{\text {med }}$ CD $\left.71^{\text {high }}\right)$ and Ery.A (Ter119 ${ }^{\text {high }}$ CD $71^{\text {high }}$ FSC ${ }^{\text {high }}$ ) are morphologically equivalent to proerythroblasts and basophilic erythroblasts, respectively, representing consecutive, early stages in erythroblast terminal differentiation (Figure 1). Proerythroblasts and basophilic erythroblasts express the EpoR, ${ }^{28-30}$ consistent with the stress responsiveness of ProEs and Ery.A. In response to a single Epo administration, the absolute number of ProEs and Ery.A increased 20- to 30-fold, their relative proportion within erythroid tissue increasing 5- to 10-fold (Figure 2). We investigated the role of Fas-mediated apoptosis in regulating the homeostasis of these cells. We found that ProEs and Ery.A coexpress Fas and FasL. Based on measurements of their cell frequency, cell survival, and Fas/FasL expression in the basal state and in mouse models of erythropoietic stress, we propose that Fas is a homeostatic regulator of erythropoiesis. Interactions between splenic early erythroblasts coexpressing Fas and FasL lead to their apoptosis, exerting a negative autoregulatory effect that limits basal erythropoietic rate. With the induction of stress, high Epo suppresses expression of erythroblast Fas and FasL, resulting in enhanced erythroblast survival and a consequent increase in erythropoietic rate.

\section{Fas mediates apoptosis of splenic early erythroblasts in the basal state in vivo}

In the basal state, ProEs and Ery.A were present at lower relative frequencies, and were undergoing higher apoptosis, in spleen than in bone marrow (Figure 3). Splenic ProEs and Ery.A expressed significantly higher levels of Fas and FasL. Single-cell analysis using multiparameter flow cytometry showed that $90 \%$ of Faspositive splenic Ery.A coexpressed FasL (Figure 4C). Further, Fas-positive Ery.A were more likely to bind annexin $\mathrm{V}$ than otherwise equivalent, Fas-negative Ery.A (Figure 4D-E). Fas expressed by freshly isolated splenic erythroblasts is functional (Figure S1). Taken together, these data suggest that interaction 


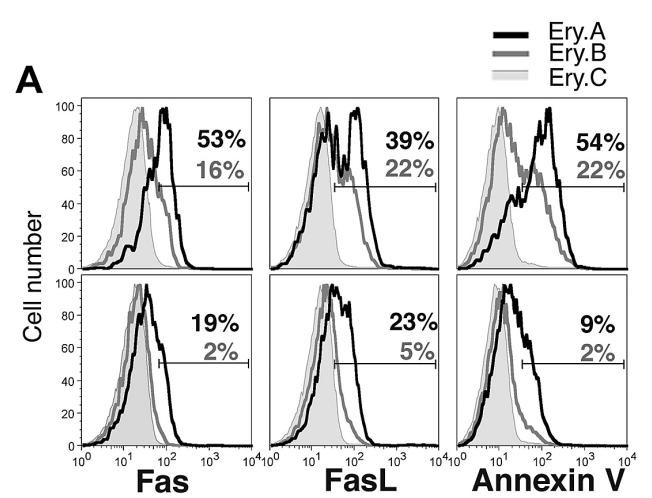

\section{B}
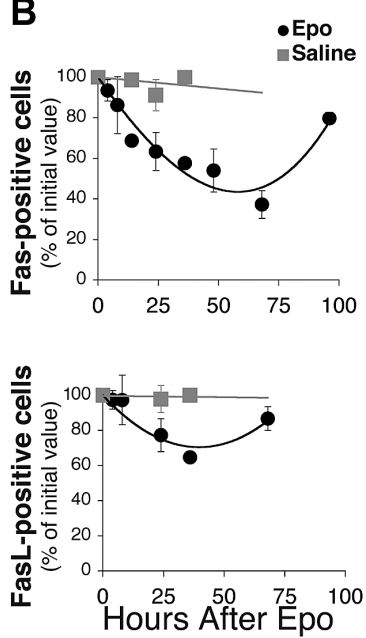

D

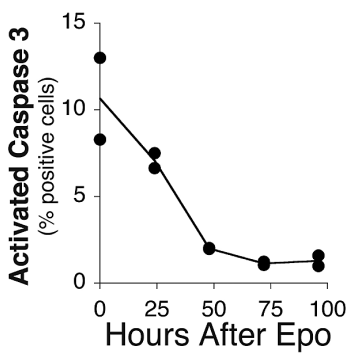

$\mathbf{E}$
C

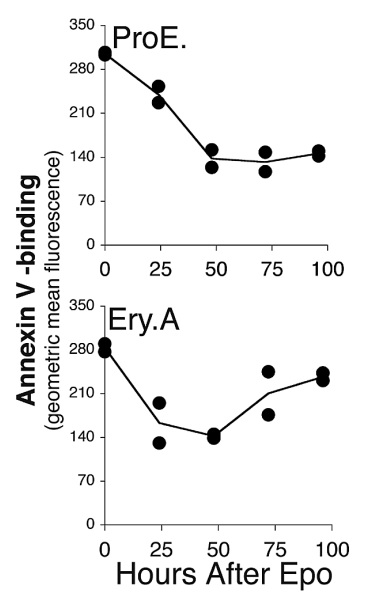

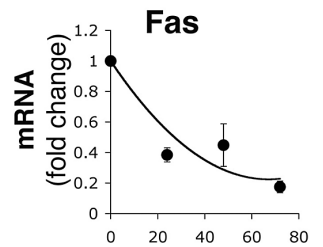

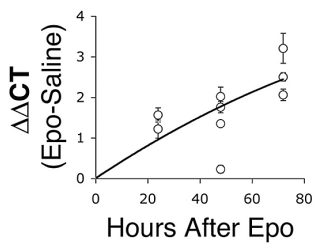

FasL
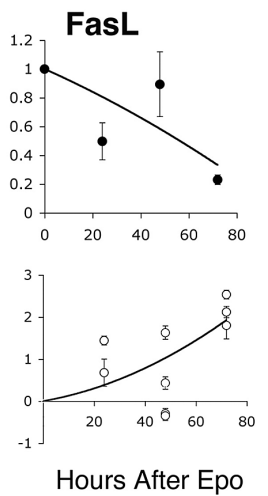
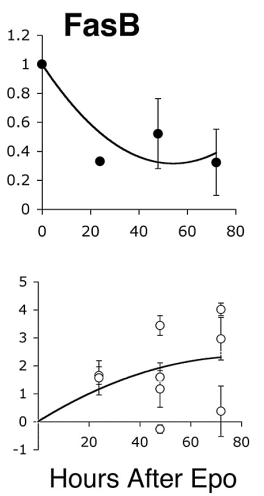

Figure 6. Suppression of erythroblast Fas and FasL and decreased apoptosis following Epo injection. Wild-type Balb/C mice were injected with a single dose of Epo $(50 \mathrm{mg} / \mathrm{kg})$ or with an equal volume of saline, and followed as described in Figure 2. Freshly isolated spleen cells were analyzed for Fas and FasL cell-surface expression and mRNAs or for apoptotic markers. (A) Representative histograms of cell-surface Fas (left panels) and FasL (middle panels) expression or annexin $V$ binding (right panels) in Ery.A, B, and C, 48 hours following injection of either saline (top panels) or Epo (bottom panels). The percentage of Ery.A positive for Fas, FasL or annexin $V$ is indicated in red, and that of Ery.B in blue. (B) Time course of cell-surface Fas and FasL following Epo or saline injection. Results pooled from 5 experiments, normalized to initial Fas or FasL levels; mean \pm SEM, $\mathrm{n}=2$ to 7 mice per time point. (C) Time course of annexin $\mathrm{V}$ binding (geometric mean fluorescence) in ProEs (top panel) and in Ery.A (bottom panel) following Epo administration. Results from duplicate mice are shown for each time point. (D) Changes in activated caspase 3 in splenic erythroblasts following Epo injection. Splenic cells were labeled for Ter119 and CD71, were fixed and permeabilized, and then labeled with an antibody specific for activated caspase 3 . Results from duplicate mice are shown for each time point. (E) Time course of Fas, FasB, and FasL mRNA expression in splenic Ery.A following injection with Epo, measured using quantitative real-time PCR, using RNA from freshly sorted splenic Ery.A. Bottom panels show the $\Delta \Delta C T$ for the indicated mRNA between mice injected with Epo and those given saline injections, normalized to actin mRNA. Each data point is the mean \pm SEM of triplicate measurements in a single experiment using 1 to 2 Epo-injected mice and 1 to 2 saline-injected mice. Two to 4 independent experiments were conducted per time point. Top panels show the mean fold change in mRNA at each time point, calculated as $2^{\Delta \Delta C T}$, using the $\Delta \Delta C T$ values shown in the bottom panels. Each data point is the mean \pm SEM for all the mice examined at each time point.

between splenic early erythroblasts coexpressing Fas and FasL leads to their apoptosis, limiting splenic Ery.A and ProE frequency, and consequently, erythropoietic rate.

Examination of $\mathrm{lpr}$ and gld mice is consistent with these conclusions, showing higher frequencies of ProEs and Ery.A in spleen compared with wild-type controls. Autoimmune anemia in some of these mice raises the possibility that the increase in ProEs and Ery.A may be due, in part, to a stress response. Recently, we found that Fas and FasL are also coexpressed by a fraction of fetal early erythroblasts, although at a lower level than in adult spleen. Nevertheless, there was a significant increase in the number of early erythroblast subsets in preimmune lpr and gld mice (manuscript submitted).

The mechanism responsible for the higher expression of Fas and FasL in splenic erythroblasts remains to be explained. It is possible, as has been suggested recently, ${ }^{73}$ that there are cell-autonomous differences between splenic and bone marrow erythroid progenitors. Alternatively, differences between the splenic and bone marrow microenvironments may differentially regulate basal expression of erythroblast Fas and FasL.
Our finding that, in vivo, both Fas and FasL are coexpressed early in terminal differentiation, contrasts with De Maria et al, ${ }^{35,64}$ who found high Fas throughout terminal differentiation in cultured erythroblasts in vitro, with FasL limited to late erythroblasts. In contrast, Krantz and colleagues $^{34}$ found both Fas and FasL expression in cultured human erythroid colony-forming cells early in terminal differentiation, but report only small numbers of cells expressing Fas $(<5 \%)$ and FasL $(13 \%)$. These lower levels may differ from those we find in vivo for several reasons, including the bone marrow origin of the cells, possible negative selection against cells expressing Fas in culture, or the high Epo levels in the culture medium compared with that found in the basal state in vivo.

\section{High Epo suppresses Fas and FasL expression during stress}

We examined $\beta$-thal mice, ts-VHL ${ }^{-1-}$ mice, pregnant mice, and mice injected with Epo. Across these distinct models of stress, expansion in splenic early erythroblasts was associated with significantly reduced cell-surface Fas and FasL (Figure 5; Tables 1-2). Further, there was an inverse correlation between Fas 
From www.bloodjournal.org at UNIV OF MASSACHUSETTS on April 3, 2008. For personal use only.

Table 3. Quantitative real-time PCR for Fas, FasL, and FasB mRNAs in chronic erythropoietic stress

\begin{tabular}{|c|c|c|c|c|c|c|}
\hline \multirow[b]{2}{*}{ Mouse strain* } & \multicolumn{2}{|c|}{ Fas } & \multicolumn{2}{|c|}{ FasL } & \multicolumn{2}{|c|}{ FasB } \\
\hline & $\Delta \Delta C T \dagger$ & $\begin{array}{l}\text { Fold decrease } \\
\text { in mRNA }\end{array}$ & $\Delta \Delta C T \dagger$ & $\begin{array}{c}\text { Fold decrease } \\
\text { in mRNA }\end{array}$ & $\Delta \Delta C T \dagger$ & $\begin{array}{l}\text { Fold decrease } \\
\text { in mRNA }\end{array}$ \\
\hline \multicolumn{7}{|l|}{ ts-VHL-I- } \\
\hline Experiment 1 & $1.12 \pm 0.29$ & - & $0.99 \pm 0.42$ & - & $1.12 \pm 0.80$ & - \\
\hline Experiment 2 & $2.61 \pm 0.09$ & - & $2.52 \pm 0.17$ & - & $2.64 \pm 0.86$ & - \\
\hline Experiment 3 & $2.05 \pm 0.17$ & - & $1.44 \pm 0.16$ & - & $2.51 \pm 0.50$ & - \\
\hline Experiment 4 & $1.00 \pm 0.13$ & - & $1.19 \pm 0.07$ & - & $0.49 \pm 0.30$ & - \\
\hline Mean & $1.70 \pm 0.38$ & 3.2 & $1.54 \pm 0.34$ & 2.9 & $1.69 \pm 0.52$ & 3.2 \\
\hline \multicolumn{7}{|l|}{$\beta$-thal } \\
\hline Experiment 1 & $1.75 \pm 0.28$ & - & $0.16 \pm 0.66$ & - & $2.29 \pm 0.90$ & - \\
\hline Experiment 2 & $3.56 \pm 0.26$ & - & $1.9 \pm 0.24$ & - & $4.3 \pm 0.09$ & - \\
\hline Experiment 3 & $2.35 \pm 0.07$ & - & $(-0.5) \pm 0.47$ & - & $2.14 \pm 0.08$ & - \\
\hline Mean & $2.55 \pm 0.53$ & 5.9 & $0.52 \pm 0.7$ & 1.4 & $2.92 \pm 0.70$ & 7.6 \\
\hline
\end{tabular}

${ }^{*}$ RNA prepared and real-time PCR carried out independently for each experiment, from Ery.A sorted from at least one $\beta$-thal or ts-VHL ${ }^{-/-}$mouse and one matched littermate.

†Mean $\pm \mathrm{SD}$ of $\Delta \Delta \mathrm{CT}$ from triplicate samples for each experiment. $\Delta \Delta \mathrm{CT}$ is the difference in cycle number for the indicated mRNAs, between template RNA from $\beta$-thal or ts- $\mathrm{VHL}^{-1-}$ mouse and its matched littermate, relative to $\beta$-actin mRNA in each sample.

$\ddagger$ Calculated as 2 to the power of the mean $\Delta \Delta C T$ for all experiments.

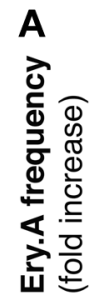

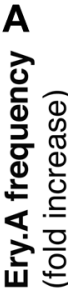
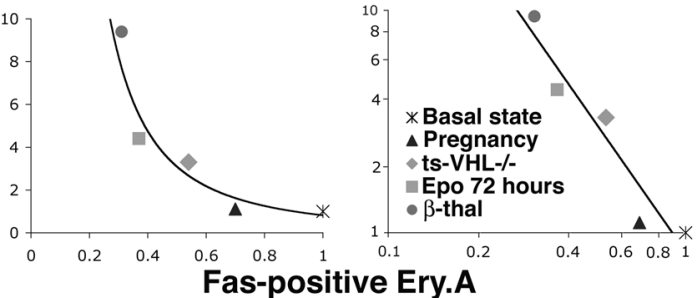

(fraction of cony.A

B

Erythroblasts

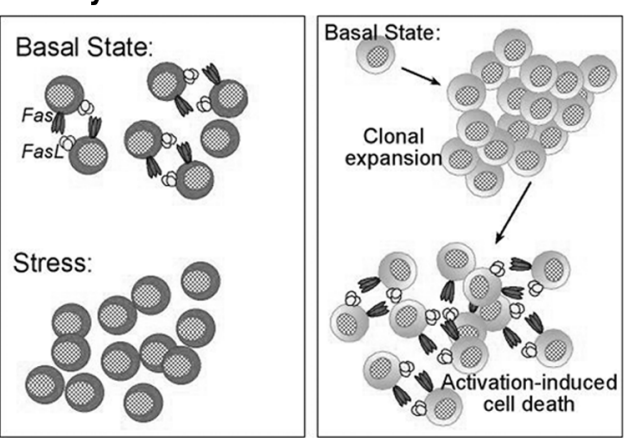

Figure 7. Frequency of splenic Ery.A is a function of their Fas expression. (A) The frequency of splenic Ery.A is a function of their Fas expression. Each data point is derived from the mean values of Ery.A frequency and Fas expression presented for each erythropoietic stress model in Figures 5-6 and Tables 1-2. The same data are presented with either linear axes (left panel) or logarithmic axes (right panel). Ery.A frequency is expressed as a ratio of mean Ery.A frequency in the stressed mice to mean Ery.A frequency in matched controls. The fraction of Fas-positive Ery.A is calculated as the ratio of mean Fas-positive Ery.A in the stressed mice to the mean Fas-positive cells in matched controls. The slope of the line in the left panel is $(-1.9)$, and the data fit the equation $y=0.82 x^{-1.9}\left(R^{2}=0.912\right)$, where $y$ is Ery.A frequency and $x$ is Ery.A Fas expression. If only chronic erythropoietic stress models are considered (ie, pregnancy and Epo injection are omitted), the equation describing the data becomes $y=1.00 x^{-1.9}\left(R^{2}=0.9999\right)$. (B) The homeostatic role of Fas in splenic early erythroblasts and in T cells. Splenic early erythroblasts coexpress Fas and FasL in the basal state, resulting in continuous apoptosis. Erythropoietic stress leads to Epo-mediated down-regulation of Fas and FasL expression and enhanced erythroblast survival, increasing erythropoietic rate. In contrast, naive $T$ cells do not express Fas and FasL in the basal state. Fas/FasL expression is induced following T-cell activation and clonal expansion, when Fas-mediated apoptosis is key in activation-induced cell death. down-regulation and Ery.A expansion across the various stress models (Figure 7A). This suggests that the degree of Fas downregulation is a function of stress and serves as a principal mechanism regulating splenic early erythroblast expansion.

Epo was sufficient to bring about down-regulation of erythroblast Fas/FasL (Figure 6). Following a single Epo administration, Ery.A Fas/FasL reached their lowest level by 48 hours. This decline was associated with enhanced Ery.A survival and their consequent expansion. There was an approximately 24-hour delay in the expansion of ProEs and Ery.A in spleen, compared with bone marrow, following Epo injection (Figure 2). This delay may be due to the higher initial Fas and FasL expression in splenic erythroblasts. There were no changes in Fas or FasL in nonerythroid cells in any of the stress models, strongly suggesting that Epo is mediating an erythroid-specific suppression of Fas and FasL. Although the largest Fas and FasL changes were in splenic Ery.A, smaller declines were also found in splenic Ery.B (Figures 5B-C; Table 1) and in bone marrow erythroblasts (Figures 5D; Table 2), cell types in which the baseline level of Fas and FasL is already low. Therefore, Epo-mediated suppression of Fas and FasL expression is likely to be an integral part of EpoR stress signaling in all EpoR-expressing erythroblasts.

Multiple mechanisms of Fas and FasL down-regulation from the cell surface have been documented, including relocalization within the cell, protease action, and transcriptional regulation. ${ }^{32}$ Here we found that mRNAs encoding Fas and FasL decline by 24 hours following Epo administration and are also significantly lower in mouse models of chronic stress compared with matched controls. These findings are consistent with EpoR-mediated suppression of Fas and FasL transcription. Alternatively, EpoR signaling may increase Fas/FasL mRNA degradation.

\section{A graded stress response may be a result of multiple Epo-activated antiapoptotic pathways}

The Stat5-bcl- $\mathrm{x}_{\mathrm{L}}$ antiapoptotic pathway in early erythroblasts is required for normal hematocrit ${ }^{16-18}$ and for an efficient stress response. ${ }^{17}$ Here we show that early erythroblast survival is also regulated through Epo-mediated suppression of Fas/FasL during stress. An increase in cell division does not appear to play a part in the acute stress response of early erythroblasts ${ }^{26}$ (Y.L. and M.S. unpublished observations, December 2004). 
It is not yet clear how, and to what extent, the dynamic range of the erythropoietic stress response can be generated through antiapoptotic signaling in early erythroblasts. It has been proposed that increasingly higher Epo levels activate a graded antiapoptotic signal, rescuing correspondingly larger fractions of early erythroblasts from apoptosis. Consistent with this model, proerythroblasts exhibit a spectrum of sensitivities to apoptosis. ${ }^{74}$ The spectrum of erythroblast Fas expression we document here suggests a potential molecular mechanism for this varying sensitivity. The mechanism giving rise to a graded antiapoptotic EpoR signaling is not yet clear but may depend on the existence of multiple antiapoptotic pathways. In addition to the Stat5-bcl- $\mathrm{x}_{\mathrm{L}}$ pathway ${ }^{16-18}$ and the suppression of Fas, several other, Epodependent antiapoptotic signals have been described in vitro, ${ }^{75-80}$ but their effect on erythroblast survival and erythropoietic rate in vivo remains to be determined.

Our data suggest that, in the basal state, the erythropoietic system continuously produces excess numbers of early erythroblasts, which become apoptotic through Fas-mediated signaling. The principal advantage of a homeostatic mechanism that relies on the production of excess cells is a reduction in the response lag time during stress. A second advantage of a homeostatic mechanism that relies on negative autoregulation of cell numbers is that it would self-correct for small perturbations, maintaining a relatively constant erythroblast population size in the basal state. Recently, using computational modeling, we identified negative feedback of this type, mediated through Fas and FasL, during the onset of erythroid development in the fetal liver (manuscript submitted).

The regulation of erythroblast homeostasis by Fas and FasL contrasts with their role in T-cell homeostasis (Figure 7B). Naive T cells in the basal state do not express Fas or FasL but do so following antigenic stimulation. In contrast, early erythroblasts in the basal state do express Fas and FasL, but this expression is down-regulated in response to stress. Other regenerating tissues such as liver, skin, or intestinal epithelium, all of which express Fas, may use a similar homeostatic mechanism to the one we delineate in erythroblasts.

\section{Acknowledgments}

We would like to thank Dr Harvey Lodish for helpful discussion; Rich Konz, Airiel Davis, Tammy Krumpoch, Barbara Gosselin, and Yuehua $\mathrm{Gu}$ of the University of Massachusetts Medical School flow cytometry core; and Stanley Klirsig for his gift of Epo.

\section{References}

1. Erslev AJ, Beutler E. Production and destruction of erythrocytes. In: Beutler E, Lichtman MA, Coller BS, Kipps TJ, eds. Williams Hematology. New York, NY: McGraw-Hill; 1995:425-441.

2. Ebert BL, Bunn HF. Regulation of the erythropoietin gene. Blood. 1999;94:1864-1877.

3. D'Andrea AD, Lodish HF, Wong GG. Expression cloning of the murine erythropoietin receptor. Cell. 1989;57:277-285

4. Remy I, Wilson IA, Michnick SW. Erythropoietin receptor activation by a ligand-induced conformation change. Science. 1999;283:990-993.

5. Livnah O, Stura EA, Middleton SA, Johnson DL, Jolliffe LK, Wilson IA. Crystallographic evidence for preformed dimers of erythropoietin receptor before ligand activation. Science. 1999;283:987990.

6. Constantinescu SN, Ghaffari S, Lodish HF. The erythropoietin receptor: structure, activation and intracellular signal transduction. Trends Endocrinol Metab. 1999;10:18-23.

7. Wojchowski DM, Gregory RC, Miller CP, Pandit AK, Pircher TJ. Signal transduction in the erythropoietin receptor system. Exp Cell Res. 1999;253: 143-156.

8. Huang LJ-s, Constantinescu SN, Lodish HF. The $\mathrm{N}$-terminal domain of Janus kinase 2 is required for Golgi processing and cell surface expression of erythropoietin receptor. Mol Cell. 2001;8:13271338.

9. Wu H, Liu X, Jaenisch R, Lodish HF. Generation of committed erythroid BFU-E and CFU-E progenitors does not require erythropoietin or the erythropoietin receptor. Cell. 1995;83:59-67.

10. Lin CS, Lim SK, D'Agati V, Costantini F. Differential effects of an erythropoietin receptor gene disruption on primitive and definitive erythropoiesis. Genes Dev. 1996;10:154-164.

11. Kieran MW, Perkins A, Orkin S, Zon L. Thrombopoietin rescues in vitro erythroid colony formation from mouse embryos lacking the erythropoietin receptor. Proc Natl Acad Sci U S A. 1996;93: 9126-9131.

12. Parganas $E$, Wang D, Stravopodis D, et al. Jak2 is essential for signaling through a variety of cytokine receptors. Cell. 1998;93:385-395.

13. Neubauer H, Cumano A, Muller M, Wu H, Huff- stadt $U$, Pfeffer K. Jak2 deficiency defines an essential developmental checkpoint in definitive hematopoiesis. Cell. 1998:93:397-409.

14. Jegalian AG, Acurio A, Dranoff G, Wu H. Erythropoietin receptor haploinsufficiency and in vivo interplay with granulocyte-macrophage colonystimulating factor and interleukin 3. Blood. 2002; 99:2603-2605.

15. Zang $H$, Sato K, Nakajima H, McKay C, Ney PA, Ihle JN. The distal region and receptor tyrosines of the Epo receptor are non-essential for in vivo erythropoiesis. EMBO J. 2001;20:3156-3166

16. Socolovsky M, Fallon AEJ, Wang S, Brugnara C, Lodish HF. Fetal anemia and apoptosis of red cell progenitors in Stat5 $\mathrm{a}^{-1-} 5 \mathrm{~b}^{-1-}$ mice: a direct role for Stat5 in bcl- $X_{L}$ induction. Cell. 1999;98:181 191.

17. Socolovsky M, Nam H, Fleming MD, Haase VH, Brugnara C, Lodish HF. Ineffective erythropoiesis in Stat5a $a^{-1-} 5 b^{-1-}$ mice due to decreased survival of early erythroblasts. Blood. 2001;98:3261 3273.

18. Cui Y, Riedlinger G, Miyoshi K, et al. Inactivation of Stat5 in mouse mammary epithelium during pregnancy reveals distinct functions in cell proliferation, survival, and differentiation. Mol Cell Biol. 2004;24:8037-8047.

19. Baxter EJ, Scott LM, Campbell PJ, et al. Acquired mutation of the tyrosine kinase JAK2 in human myeloproliferative disorders. Lancet. 2005;365 1054-1061.

20. Kralovics R, Passamonti F, Buser AS, et al. A gain-of-function mutation of JAK2 in myeloproliferative disorders. N Engl J Med. 2005;352:17791790.

21. Levine RL, Wadleigh M, Cools J, et al. Activating mutation in the tyrosine kinase JAK2 in polycythemia vera, essential thrombocythemia, and my eloid metaplasia with myelofibrosis. Cancer Cell. 2005;7:387-397.

22. James C, Ugo V, Le Couedic JP, et al. A unique clonal JAK2 mutation leading to constitutive signalling causes polycythaemia vera. Nature. 2005 434:1144-1148.

23. Stephenson JR, Axelrad AA, McLeod DL, Shreeve MM. Induction of colonies of hemoglobin-synthesizing cells by erythropoietin in vitro. Proc Natl Acad Sci U S A. 1971;68:1542-1546.
24. Gregory CJ, Tepperman AD, McCulloch EA, Till JE. Erythropoietic progenitors capable of colony formation in culture: response of normal and genetically anemic $W / W^{V}$ mice to manipulations of the erythron. J Cell Physiol. 1974;84:1-12.

25. Peschle C, Magli MC, Cillo C, et al. Kinetics of erythroid and myeloid stem cells in post-hypoxia polycythaemia. Br J Haematol. 1977;37:345-352.

26. Papayannopoulou T, Finch CA. On the in vivo action of erythropoietin: a quantitative analysis. J Clin Invest. 1972;51:1179-1185.

27. Koury MJ, Bondurant MC. Erythropoietin retards DNA breakdown and prevents programmed death in erythroid progenitor cells. Science. 1990; 248:378-381.

28. Wickrema A, Bondurant MC, Krantz SB. Abundance and stability of erythropoietin receptor mRNA in mouse erythroid progenitor cells. Blood. 1991;78:2269-2275.

29. Wickrema A, Krantz SB, Winkelmann JC, Bondurant MC. Differentiation and erythropoietin receptor gene expression in human erythroid progenitor cells. Blood. 1992;80:1940-1949.

30. Broudy VC, Lin N, Brice M, Nakamoto B, Papayannopoulou T. Erythropoietin receptor characteristics on primary human erythroid cells. Blood. 1991;77:2583-2590.

31. Nagata S, Golstein P. The Fas death factor. Science. 1995;267:1449-1456.

32. Curtin JF, Cotter TG. Live and let die: regulatory mechanisms in Fas-mediated apoptosis. Cell Signal. 2003;15:983-992.

33. Wajant $\mathrm{H}$. The Fas signaling pathway: more than a paradigm. Science. 2002;296:1635-1636.

34. Dai CH, Price JO, Brunner T, Krantz SB. Fas ligand is present in human erythroid colonyforming cells and interacts with Fas induced by interferon gamma to produce erythroid cell apoptosis. Blood. 1998;91:1235-1242.

35. De Maria R, Testa U, Luchetti L, et al. Apoptotic role of Fas/Fas ligand system in the regulation of erythropoiesis. Blood. 1999;93:796-803.

36. Oda A, Nishio M, Sawada K. Stem cell factor regulation of Fas-mediated apoptosis of human erythroid precursor cells. J Hematother Stem Cell Res. 2001;10:595-600.

37. Dror Y, Freedman MH. Shwachman-Diamond 
syndrome marrow cells show abnormally increased apoptosis mediated through the Fas pathway. Blood. 2001;97:3011-3016.

38. Claessens YE, Park S, Dubart-Kupperschmitt A et al. Rescue of early stage myelodysplastic syndrome-deriving erythroid precursors by the ectopic expression of a dominant negative form of FADD. Blood. 2005;105:4035-4042.

39. Gersuk GM, Beckham C, Loken MR, et al. A role for tumour necrosis factor-alpha, Fas and Fasligand in marrow failure associated with myelodysplastic syndrome. Br J Haematol. 1998;103: 176-188.

40. Gersuk GM, Lee JW, Beckham CA, Anderson J, Deeg HJ. Fas (CD95) receptor and Fas-ligand expression in bone marrow cells from patients with myelodysplastic syndrome. Blood. 1996;88: 1122-1123.

41. Silvestris F, Tucci M, Cafforio P, Dammacco F. Fas-L up-regulation by highly malignant myeloma plasma cells: role in the pathogenesis of anemia and disease progression. Blood. 2001;97:11551164.

42. Silvestris F, Cafforio P, Tucci M, Dammacco F. Negative regulation of erythroblast maturation by Fas-L(+)/TRAIL $(+)$ highly malignant plasma cells: a major pathogenetic mechanism of anemia in multiple myeloma. Blood. 2002;99:1305-1313.

43. Schrier SL, Centis F, Verneris M, Ma L, Angelucc $\mathrm{E}$. The role of oxidant injury in the pathophysiology of human thalassemias. Redox Rep. 2003;8: 241-245.

44. French LE, Hahne M, Viard I, et al. Fas and Fas ligand in embryos and adult mice: ligand expression in several immune-privileged tissues and coexpression in adult tissues characterized by apoptotic cell turnover. J Cell Biol. 1996;133:335343.

45. Cheema ZF, Wade SB, Sata M, Walsh K, Sohrabji F, Miranda RC. Fas/Apo [apoptosis]-1 and associated proteins in the differentiating cerebral cortex: induction of caspase-dependent cell death and activation of NF-kappaB. J Neurosci. 1999;19:1754-1770.

46. Raoul C, Henderson CE, Pettmann B. Programmed cell death of embryonic motoneurons triggered through the Fas death receptor. J Cell Biol. 1999;147:1049-1062.

47. Nat R, Radu E, Regalia T, Popescu LM. Apoptosis in human embryo development, 3: Fas-induced apoptosis in brain primary cultures. J Cell Mol Med. 2001;5:417-428.

48. De Paepe ME, Rubin LP, Jude C, Lesieur-Brooks AM, Mills DR, Luks FI. Fas ligand expression coincides with alveolar cell apoptosis in lategestation fetal lung development. Am J Physiol Lung Cell Mol Physiol. 2000;279:L967-976.

49. De Paepe ME, Mao Q, Embree-Ku M, Rubin LP, Luks FI. Fas/FasL-mediated apoptosis in perinatal murine lungs. Am J Physiol Lung Cell Mol Physiol. 2004;287:L730-L742.

50. Nagata S, Suda T. Fas and Fas ligand: Ipr and gld mutations. Immunol Today. 1995;16:39-43.

51. Schneider E, Moreau G, Arnould A, et al. Increased fetal and extramedullary hematopoiesis in Fas-deficient C57BL/6-Ipr/lpr mice. Blood. 1999;94:2613-2621.

52. Ogasawara J, Watanabe-Fukunaga R, Adachi M, et al. Lethal effect of the anti-Fas antibody in mice. Nature. 1993;364:806-809.

53. Fuller CL, Ravichandran KS, Braciale VL. Phosphatidylinositol 3-kinase-dependent and -independent cytolytic effector functions. J Immunol. 1999;162:6337-6340.

54. Zhang J, Socolovsky M, Gross AW, Lodish HF. Role of Ras signaling in erythroid differentiation of mouse fetal liver cells: functional analysis by a flow cytometry-based novel culture system. Blood. 2003;102:3938-3946.

55. Kong Y, Zhou S, Kihm AJ, et al. Loss of alphahemoglobin-stabilizing protein impairs erythropoiesis and exacerbates beta-thalassemia. J Clin Invest. 2004;114:1457-1466.

56. Harder KW, Quilici C, Naik E, et al. Perturbed myelo/erythropoiesis in Lyn-deficient mice is similar to that in mice lacking the inhibitory phosphatases SHP-1 and SHIP-1. Blood. 2004;104:39013910.

57. Angelin-Duclos $C$, Domenget C, Kolbus A, Beug $\mathrm{H}$, Jurdic $\mathrm{P}$, Samarut J. Thyroid hormone T3 acting through the thyroid hormone alpha\} receptor is necessary for implementation of erythropoiesis in the neonatal spleen environment in the mouse. Development. 2005;132:925-934.

58. Halupa A, Bailey ML, Huang K, Iscove NN, Levy DE, Barber DL. A novel role for STAT1 in regulating murine erythropoiesis: deletion of STAT1 results in overall reduction of erythroid progenitors and alters their distribution. Blood. 2005;105:552 561.

59. Spike BT, Dirlam A, Dibling BC, et al. The Rb tumor suppressor is required for stress erythropoiesis. EMBO J. 2004;23:4319-4329.

60. Pootrakul P, Sirankapracha P, Hemsorach S et al. A correlation of erythrokinetics, ineffective erythropoiesis, and erythroid precursor apoptosis in Thai patients with thalassemia. Blood. 2000;96: 2606-2612.

61. Vermes I, Haanen C, Seffens-Nakken H, Reutelingsperger C. A novel assay for apoptosis: Flow cytometric detection of phosphatidylserine expression on early apoptotic cells using fluorescein labelled annexin V. J Immunol Methods. 1995; 184:39-51.

62. Villa P, Kaufmann SH, Earnshaw WC. Caspases and caspase inhibitors. Trends Biochem Sci. 1997;22:388-393

63. Schmid I, Uittenbogaart CH, Giorgi JV. Sensitive method for measuring apoptosis and cell surface phenotype in human thymocytes by flow cytometry. Cytometry. 1994;15:12-20.

64. De Maria R, Zeuner A, Eramo A, et al. Negative regulation of erythropoiesis by caspase-mediated cleavage of GATA-1 [see comments]. Nature. 1999;401:489-493.

65. Yang B, Kirby S, Lewis J, Detloff PJ, Maeda N, Smithies O. A mouse model for beta 0-thalassemia. Proc Natl Acad Sci U S A. 1995;92:1160811612.

66. Haase VH, Glickman JN, Socolovsky M, Jaenisch
R. Vascular tumors in livers with targeted inactivation of the von Hippel-Lindau tumor suppressor. Proc Natl Acad Sci U S A. 2001;98:15831588

67. Rankin EB, Higgins DF, Walisser JA, Johnson RS, Bradfield CA, Haase VH. Inactivation of the arylhydrocarbon receptor nuclear translocator (Arnt) suppresses von Hippel-Lindau diseaseassociated vascular tumors in mice. Mol Cell Biol. 2005;25:3163-3172.

68. Rankin EB, Tomaszewski JE, Haase VH. Renal cyst development in mice with conditional inactivation of the von-Hippel-Lindau tumor suppressor. Cancer Res. 2006;66:2576-2583.

69. Warrell DA, Cox TM, Firth JD, Benz EJJ. Oxford Textbook of Medicine. 4th ed. Oxford, United Kingdom: Oxford University Press; 2003.

70. Broudy VC, Lin NL, Priestely GV, Nocka K, Wolf NS. Interaction of stem cell factor and its receptor c-kit mediates lodgement and acute expansion of hematopoietic cells in the murine spleen. Blood. 1996;88:75-81.

71. von Lindern M, Zauner W, Mellitzer G, et al. The glucocorticoid receptor cooperates with the erythropoietin receptor and c-Kit to enhance and sustain proliferation of erythroid progenitors in vitro. Blood. 1999;94:550-559.

72. Bauer A, Tronche F, Wessely $\mathrm{O}$, et al. The glucocorticoid receptor is required for stress erythropoiesis. Genes Dev. 1999;13:2996-3002.

73. Lenox LE, Perry JM, Paulson RF. BMP4 and Madh5 regulate the erythroid response to acute anemia. Blood. 2005;105:2741-2748.

74. Kelly LL, Koury MJ, Bondurant MC, Koury ST, Sawyer ST, Wickrema A. Survival or death of individual proerythroblasts results from differing erythropoietin sensitivities: a mechanism for controlling rates of erythrocyte production. Blood. 1993;82:2340-2352.

75. Bouscary D, Pene F, Claessens YE, et al. Critical role for PI 3-kinase in the control of erythropoietin-induced erythroid progenitor proliferation. Blood. 2003;101:3436-3443.

76. Haseyama Y, Sawada K, Oda A, et al. Phosphatidylinositol 3-kinase is involved in the protection of primary cultured human erythroid precursor cells from apoptosis. Blood. 1999;94:1568-1577.

77. Chung IJ, Dai C, Krantz SB. Stem cell factor increases the expression of FLIP that inhibits IFNgamma-induced apoptosis in human erythroid progenitor cells. Blood. 2003;101:1324-1328.

78. van den Akker E, van Dijk TB, Schmidt $U$, et al. The Btk inhibitor LFM-A13 is a potent inhibitor of Jak2 kinase activity. Biol Chem. 2004;385:409413.

79. Kapur R, Zhang L. A novel mechanism of cooperation between c-Kit and erythropoietin receptor stem cell factor induces the expression of Stat5 and erythropoietin receptor, resulting in efficient proliferation and survival by erythropoietin. J Biol Chem. 2001;276:1099-1106.

80. Shibayama H, Takai E, Matsumura I, et al. Identification of a cytokine-induced antiapoptotic molecule anamorsin essential for definitive hematopoiesis. J Exp Med. 2004;199:581-592. 